\title{
Forage grasses under drought stress in conditions of Poland
}

\author{
Mariola Staniak ${ }^{1} \cdot$ Anna Kocoń $^{2}$
}

Received: 12 January 2015/Revised: 10 March 2015/Accepted: 18 May 2015/Published online: 29 May 2015

(C) The Author(s) 2015. This article is published with open access at Springerlink.com

\begin{abstract}
Crop performance and yield are the results of genotypic expression as modulated by continuous interaction with the environment. Among the environmental factors, water is one of the most important, which limits the crop production on a global basis. Water resources in the world are steadily diminishing, and in many areas, including Poland, more frequent periods of drought are observed. There are many problems that are specifically related to water scarcity: an extremely dynamic nature of plant water status, relationship to the severity of the effects of water, time stress during ontogeny of plants, and the interaction of water stress with other environmental variables. The paper presents a review of recent literature on the effect of the grasses to drought stress at the level of physiological processes and the possibility of yielding. A better understanding of how long-term growth and yield are affected by water stress should aid in improving irrigation efficiency and practices, in modifying plants for more efficient water use, and in developing effective dryland agriculture.
\end{abstract}

Keywords Stress · Drought · Grass · Yielding · Physiological process

Communicated by A. K. Kononowicz.

Mariola Staniak

staniakm@iung.pulawy.pl

1 Department of Forage Crop Production, Institute of Soil Science and Plant Cultivation, State Research Institute, Czartoryskich Str. 8, 24-100 Puławy, Poland

2 Department of Plant Nutrition and Fertilization, Institute of Soil Science and Plant Cultivation, State Research Institute, Czartoryskich Str. 8, 24-100 Puławy, Poland

\section{Introduction}

Water covers $72 \%$ of the surface of our planet, but according to the Report of the World Meteorological Organization (WMO 2004), salt and oceanic waters constitute over $97 \%$ of the water on the Earth. Due to their salinity, they are not suitable for human consumption. Fresh water constitutes not more than $2.5 \%$, only $0.6 \%$ of which is available to man as a source of drinking water, as the rest is trapped in glaciers and snows. According to the UN report (Water in a Changing World 2009), average amount of water per inhabitant of the Earth has been steadily decreasing since 1970 , and over the next 20 years, it will decrease by one-third, which in $20 \%$ is presumably the result of climate change. The increased concentration of greenhouse gases causes the changes of different elements of the climate, such as temperature, precipitation, soil moisture, and sea level. It is estimated that by 2100 , the average air temperature will have risen by 1.4 to even $5.8{ }^{\circ} \mathrm{C}$ (EEA 2004; IPCC 2014; Kozyra et al. 2009; Wigley and Raper 2001). The temperature rise causes a danger of reducing the amount of rain and snow, which can deepen the deficit of water, especially during the summer and can cause a higher occurrence of drought. Many aspects of climate change and associated impacts will continue for centuries, even if anthropogenic emissions of greenhouse gases are stopped. The risks of abrupt or irreversible changes increase as the magnitude of the warming increases (IPCC-Intergovernmental Panel on Climate Change 2014). Rapid changes in breeding, agricultural techniques, and other aspects of human activity directly related to crop production should be introduced in response to the emerging forecasts. Forage grasses are an important group of crops, characterized by a high yielding potential of dry matter, protein, and energy, which deliver a high- 
value feed for ruminants. The aim of this paper is to present the latest research on the reaction of different species of forage grasses to water deficits in the soil.

\section{Droughts in Poland}

Drought is an extreme weather phenomenon, a type of atmospheric anomaly caused by the lack of rain or repetitive smaller-than-average rainfall (Paulo and Pereira 2006). It occurs in areas with both large and small amounts of rainfall. It is a complex phenomenon, difficult to be clearly identified. It occurs periodically, in different seasons and with different intensity. In agriculture, drought is a prolonged shortage of soil water in a given place, acting on a specific plant species or cultivar in a certain period of time (Łabędzki 2006a). It causes the deterioration of the conditions for growth and development and the reduction of crop yields.

For many years, scientists have devoted a lot of attention to drought, especially if it is caused by the deficit of rainfall. This problem is also of interest in Poland, due to the fact that there are more and more frequent periodic water shortages on large areas of Poland, which cause large losses in agricultural production (Górski et al. 2008). Poland belongs to the group of countries with the fewest resources of surface water in Europe. There is about $1419 \mathrm{~m}^{3}$ of water per capita per year, which at the average for Eastern Europe being $14818 \mathrm{~m}^{3}$, means a medium to high risk of drought (Revenga et al. 2000). Almost all central, north-western, and central-eastern parts of Poland are classified as the driest regions (Łabędzki 2006a). They are characterized by the most frequent and the strongest droughts with very long rainless periods or with the series of rainfalls below average. According to Bąk (2004) and Kędziora (2005), the largest rainfall deficit occurs in the Wielkopolska Lakeland, especially in the area of Kujawy, where rainfall amounts to average $514 \mathrm{~mm}$, and is one of the lowest in the country. The analysis of weather conditions in the Kujawy region in the years of 1945-2003 showed a positive tendency in temperature and a negative one in rainfall during the growing season, which was accompanied by an increasing number of dry periods (Bak and Łabędzki 2003).

Agriculture is the largest user of water. It is estimated that in the world, over $70 \%$ of the uptaken water is used for soil irrigation (Water in a Changing World. The United Nations World Water Development Report 3-WWDR3 2009). In Europe, it does not play such an important role. In the countries of the north part of the continent, 3-15\% of the agricultural land is irrigated, while in the South, about $30 \%$ (Mioduszewski 2006). Agriculture in Poland relies mainly on rain water, hence only about $0.5 \%$ of the farmland and forest land are irrigated (Statistical Yearbook 2013). Frequent rainfall deficiencies are a real threat to agricultural production. Droughts can occur at different times of the year, with varying intensity, duration, and scope. In the system of agricultural drought monitoring, meteorological conditions causing drought are determined by climatic water balance (CWB). According to Doroszewski et al. (2012), in recent years in Poland, in spring and early summer, CWB values have been getting lower and lower, which means that droughts are becoming more and more severe (Fig. 1).

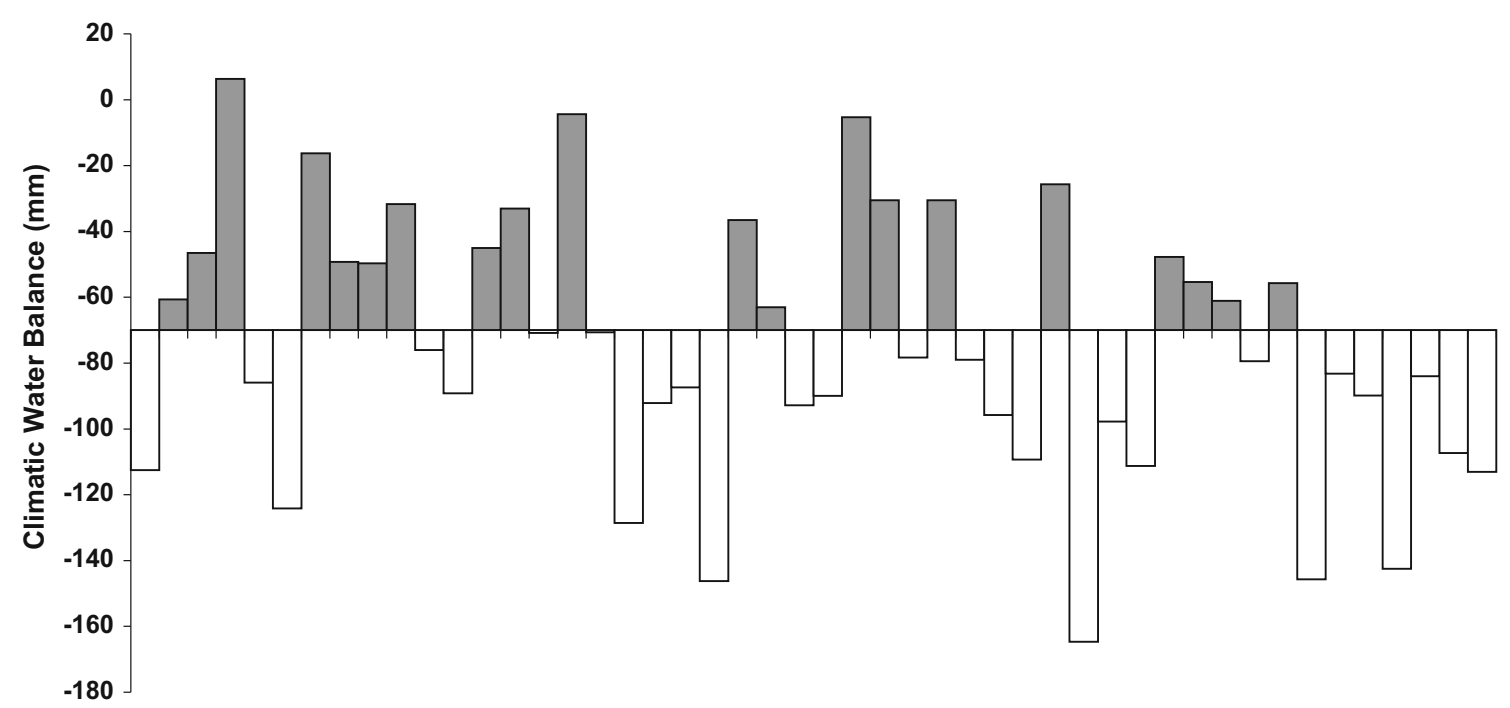

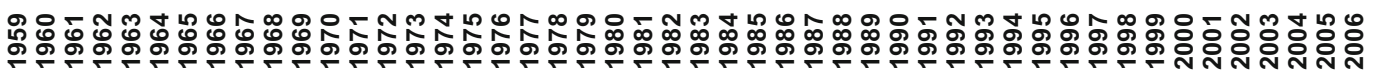

Fig. 1 Climatic Water Balance (CWB) from May to June in Poland in the years 1959-2006. [Kozyra et al. 2009] 
Spring droughts are generally the cause of the reduction in yield of spring cereals, the first regrowth of meadow sward, and productivity of pastures, summer droughtsfield forage crops, and the second regrowth of meadow sward, while the autumn ones-winter cereals (Labędzki 2006b). A long-term catastrophic drought in 1992, which covered almost all territory of Poland, caused a reduction in the harvest of the main crops on average by $25 \%$, while yields of hay from the meadows were smaller on average by $27 \%$ compared to the average yield in the years of 1986-1990 (Łabędzki 2006b). The consequence of this was the increase in food prices and the lack of feed for animals. Extreme drought in 2006 was the manifestation of the tendency for water deficiency. It caused average yield of certain crops to decrease by up to $30 \%$ (Doroszewski et al. 2012). The periods of drought occur in Poland more and more often. According to the report by the Institute of Meteorology and Water Management (Drought in Poland 2006), the frequency of the occurrence of dry years in Poland in the period of 1951-1981 was 6 (on average, every 5 years), whereas in the period of 1982-2006, up to 13 (on average, every 2 years). It can therefore be concluded that the climate in Poland has been clearly changing in recent years, and extreme weather phenomena, such as droughts, have become characteristics of the Polish climate. This entails a range of adverse ecological and economic effects.

\section{The physiological reaction of plants to drought}

Stress factors are environmental factors whose effects can lead to reversible or irreversible disturbance of the functioning of the plant and its structure. If the severity of the exposure to the stress factor does not exceed the genetically determined resistance of the plant, it adopts to the changed conditions, while a prolonged exposure to the stressor, with high intensity, can lead to a permanent damage to cells, tissues, and organs and in extreme cases even to the death of the whole plant (Chaves and Oliveira 2004).

The deficit of water significantly limits the growth, development, and above all, the yielding of crops. Moderate water stress first causes the inhibition of growth and speed of cell division in leaves. The rate of growth starts to decrease when the water content falls below the point of tissue saturation with water. A longer stress can lead to disturbances in the metabolism of plants, in particular in the photosynthetic activity of the plant. Under drought conditions, the rate of photosynthesis decreases, which is probably related to a decrease in the RuBisCo activity, the reduction of stomata conductance, and reduced availability of $\mathrm{CO}_{2}$ (Hura et al. 2007; Jones 1998; Kalaji and Łoboda 2010).
At the cellular level, the shortage of moisture results the disturbance of water balance of the plant by a decrease in water potential in the cells. Various metabolites which lower osmotic potential and protect cellular structures are accumulated (Ozturk and Ayolin 2004). A prolonged and increasing stress adversely affects the structure of the chloroplasts, causing the destruction of the thylakoid membranes, which leads to the damage of photosystems, mainly of PS II (Krupa and Baszyński 1989; Starck 1995). The disturbance of cell membranes results in the changes in the content of ions and various metabolites and overproduction of active oxygen. This can cause a lot of irreversible adverse consequences for the plant, including death of cells and dieback of tissues (Kacperska 1996, 2004).

In the conditions of water deficit, plants reveal the mechanisms to combat dehydration. First of all, they increase the content of abscisic acid (ABA) and synthesize stress proteins which protect cell membranes and participate in osmoregulation (Farooq et al. 2009; Vierling and Kimpel 1992). The increase in the concentration of ABA in cells leads to the reduction of transpiration by closing stomata and, in extreme cases, to the reduction of the surface of transpiration through leaf drop. Moreover, abscisic acid has an inhibitory effect on the growth of the shoots, but at the same time stimulates the growth and development of roots, which largely helps to overcome stress (Farooq et al. 2009; Munns and Scharp 1993). Amino acid proline, which is an important structural component of the cell wall of higher plants, is a nonspecific substance of anti-stress activity. Its protective activity also includes stabilizing the structure and function of cell membranes in the stage of cell dehydration, and maintaining a constant level of $\mathrm{pH}$ in the cytoplasm. A substantial and rapid accumulation of this amino acid occurs in the cells in the conditions of water deficit. Due to their osmoregulation properties, plants can efficiently extract water from the soil and retain it longer (Bokhari and Trent 1985; Karolewski 1996). According to Hanson and Hitz (1982), the level of free proline in the leaves subjected to water stress is by 20 to 100 -fold higher than in well-hydrated leaves. This amino acid also accelerates the repair of damages in the restitution stage (Bandurska 1999). Young plants accumulate more proline than older ones under drought conditions (Bandurska et al. 2008; Karolewski 1996).

The regulation of gene expression which contributes to changes in the metabolism of carbohydrates is an important mechanism for the acclimation of plants to the changing environmental conditions. According to Paul et al. (2001), disaccharide trehalose is essential to regulate the photosynthesis processes and distribution of photoassimilates, as well as to increase the resistance of plants to drought. Trehalose is commonly found in fungi, microorganisms, 
and higher plants, including poikilohydric grasses. The use of the latest research methods and modern equipment with high sensitivity revealed the prevalence of this substance in plants subjected to drought stress (Starck 2010).

\section{Adaptation and acclimatization}

The survival of the plant and produce of the agricultural yield in the environment including a stress factor depend on the plant resistance to a stressor. This depends on three basic elements: properties of the organism, which determine the vulnerability or strength of its structures to stress, the organism's ability to damage reparation, and to adaptation or acclimatization (Kacperska 1991; Starck 1995). Adaptation results from the changes in the genome of an individual in the course of evolution, resulting from mutations or breeding. It is a steady process which leads to the differentiation of plants in terms of morphology and metabolism, the examples being succulents, sclerophytes, or ephemerides. On the other hand, acclimatization involves the modification of the structure and functions of the individual during its ontogeny in response to a stress factor, and is not inherited. It allows for minimizing the damage and a better adaptation to environmental conditions (Hanson and Nelsen 1985).

Both adaptation and acclimatization may be the result of two adaptation strategies, i.e., the ability of stress avoidance and tolerance to its effects. Avoiding stress involves producing chemical or physical barriers which protect the plant from dehydration or prevent the stressor from entering tissues or cells, for example, by adjusting the life cycle to seasonal changes in environmental conditions. This phenomenon involves, for example, a very early flowering and seeds forming before the period of the greatest severity of drought, which can be observed, for example, in some Mediterranean cultivars of Dactylis glomerata (Volaire and Leliévre 2005). Plants adapt to an increasing water scarcity by the reduction of transpiration and efficient water uptake, conduction, and storage (Blum 2009). In most of grasses, the root system is adapted to absorption of a large amounts of water from a relatively small area due to fact that the main root mass is situated in the upper soil layer $(0-20 \mathrm{~cm})$. In contrast, the species considered to be resistant to drought are characterized with well-developed roots which can reach down to the depth of $2 \mathrm{~m}$, like in Festuca arundinacea (Carrow 1996; Eagles et al. 1999; Hull 1997; Thomas 1994; Wilman et al. 1998). The reduction of transpiration occurs through closing the stomata, increasing the thickness of the cuticle, covering the leaves with tomentum, and limiting the size or reducing the number of leaves.

\section{Photosynthetic activity of pasture grasses under drought stress}

Physiological processes occurring in plants under stress can be examined with a number of methods. The most thorough methods examine the process of photosynthesis, which is one of the most important processes in plants, but at the same time, it is particularly sensitive to stress factors (Kalaji and Łoboda 2010). Under optimal growing conditions, the yield of plants depends on the intensity of this process and is reduced by the loss of biomass resulting from respiration (Lawlor 1995, Nalborczyk 1996). The impact of drought on the intensity of gas exchange depends on its duration, level of activity, and the physiological age of leaves. The size of assimilation area, the length of life, and the period of the capacity of assimilation organs to efficient photosynthesis also play an important role in biomass production. A young leaf becomes a producer only when it reaches half of the final size, and an aging leaf ceases to be a donor of assimilates. During this period, young leaves of the plants of $\mathrm{C}_{3}$ photosynthesis export about 50-60\%, and the leaves of plants with $\mathrm{C}_{4}$ photosynthesis up to $80 \%$ of assimilates (Starck 2002). The first symptoms of turgidity loss appear first on older leaves and they, first of all, reduce photosynthesis and translocation of assimilates. In the initial period of drought, reductions in gas exchange of plants are caused by closing of stomata, while under the conditions of prolonged stress, there are disorders in cellular metabolism. According to Kacperska (1991), inhibition of photosynthesis is one of the features of plants, which has a high diagnostic value and can help to assess the response of plants to stress. Also Nalborczyk (1996) indicates that the analysis of the evolution of gas exchange in the canopy during the growing season of plants should be the starting point in the study on increasing the productivity of plants. It could also become a background for considerations on the impact of agronomic factors.

Reduction of the intensity of photosynthesis and transpiration in fodder grasses under drought stress was indicated by many authors (Jones et al. 1980, Olszewska 2006, 2009, Xu and Zhou 2005). According to Olszewska et al. (2010), among the tested species of grasses (Lolium perenne, Dactylis glomerata, Festuca pratensis, Phleum pratense, and Arrhenatherum elatius), the largest decrease in $\mathrm{CO}_{2}$ assimilation under water stress was found for $F$. pratensis, while in D. glomerata, the reduction was small and insignificant. Similar dependencies occurred in the course of transpiration. In the research of Rumasz-Rudnicka (2010), the irrigation of Lolium westerwoldicum caused the increase in the intensity of photosynthesis by $28 \%$, and transpiration by about $64 \%$ (Table 1). Own studies also showed a large reduction in the intensity of photosynthesis and transpiration in D. glomerata, F. pratensis, Festulolium 
Table 1 Effect of soil moisture on intensity of photosynthesis, transpiration, and water-use efficiency in L. westerwoldicum (Rumasz-Rudnicka 2010)

\begin{tabular}{|c|c|c|c|c|c|}
\hline Specification & Irrigation & I regrowth & II regrowth & IIIregrowth & Mean \\
\hline \multirow[t]{2}{*}{ Intensity of photosynthesis net $\left[\mu \mathrm{mol} \mathrm{CO} \mathrm{CO}^{-2} \mathrm{~s}^{-1}\right]$} & + & $5.98^{\mathrm{b}}$ & $12.61^{\mathrm{b}}$ & $11.47^{\mathrm{a}}$ & $10.02^{\mathrm{b}}$ \\
\hline & - & $4.08^{\mathrm{a}}$ & $9.19^{\mathrm{a}}$ & $10.31^{\mathrm{a}}$ & $7.86^{\mathrm{a}}$ \\
\hline \multirow[t]{2}{*}{ Intensity of transpiration $\left[\mathrm{mmol} \mathrm{H}_{2} \mathrm{O} \mathrm{m}^{-2} \mathrm{~s}^{-1}\right.$ ] } & + & $3.45^{\mathrm{b}}$ & $1.31^{\mathrm{b}}$ & $2.76^{\mathrm{b}}$ & $2.51^{b}$ \\
\hline & - & $2.09^{\mathrm{a}}$ & $1.05^{\mathrm{a}}$ & $1.48^{\mathrm{a}}$ & $1.54^{\mathrm{a}}$ \\
\hline \multirow[t]{2}{*}{ Water-use efficiency WUE $\left[\mathrm{mmol} \mathrm{mol}{ }^{-1}\right]$} & + & $1.81^{\mathrm{a}}$ & $10.64^{\mathrm{a}}$ & $4.22^{\mathrm{a}}$ & $4.16^{\mathrm{a}}$ \\
\hline & - & $2.71^{\mathrm{a}}$ & $9.44^{\mathrm{a}}$ & $9.52^{\mathrm{b}}$ & $5.83^{\mathrm{b}}$ \\
\hline
\end{tabular}

Values in the same column followed by a different letter are significantly different $(p<0.05$; Tukey's test)

Fig. 2 Effect of soil moisture on the intensity of photosynthesis in different plant development stages of selected grass species (own study)
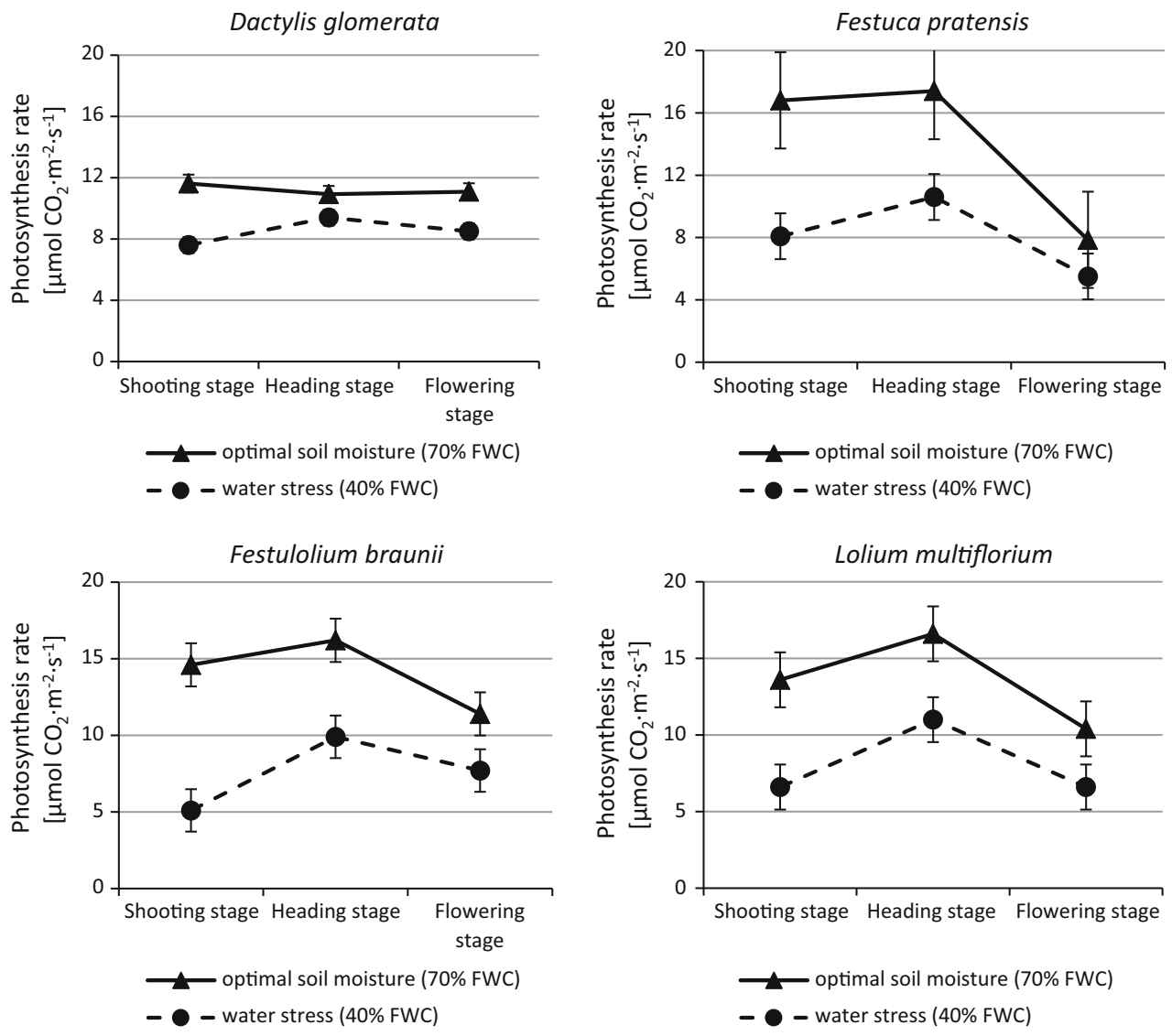

braunii, and Lolium multiflorum under the conditions of limited soil moisture (Staniak 2013). The biggest inhibition of the photosynthesis process was found in F. braunii (on average by $46 \%$ ), and the smallest in D. glomerata (on average by $27 \%$ ). All grasses reacted strongest in the critical period-the shooting stage (Figs. 2, 3).

\section{Yielding of forage grasses under drought stress}

From the point of view of yielding biology, a plant resistant to stress is characterized by a high yielding stability, i.e., in adverse environmental conditions, it yields a little lower than the yield of the plants grown under optimal conditions. Such plants are capable of maintaining the life processes at almost the same level in the environmental conditions much different from the optimal (Dziadczyk 2002).

Yielding of forage grasses is closely dependent on soil moisture, i.e., they react to a higher water content in the soil with a significant increase of yield (Jurek 1994; Olszewska 2009; Olszewska et al. 2010; Staniak 2013). The composition of the sward is also very important. The more species-rich communities produced more biomass as a result of a large and positive complementarity effect that outweighed a small negative selection effect (Van Peer 
Fig. 3 Effect of soil moisture on the intensity of transpiration in different plant development stages of selected grass species (own study)
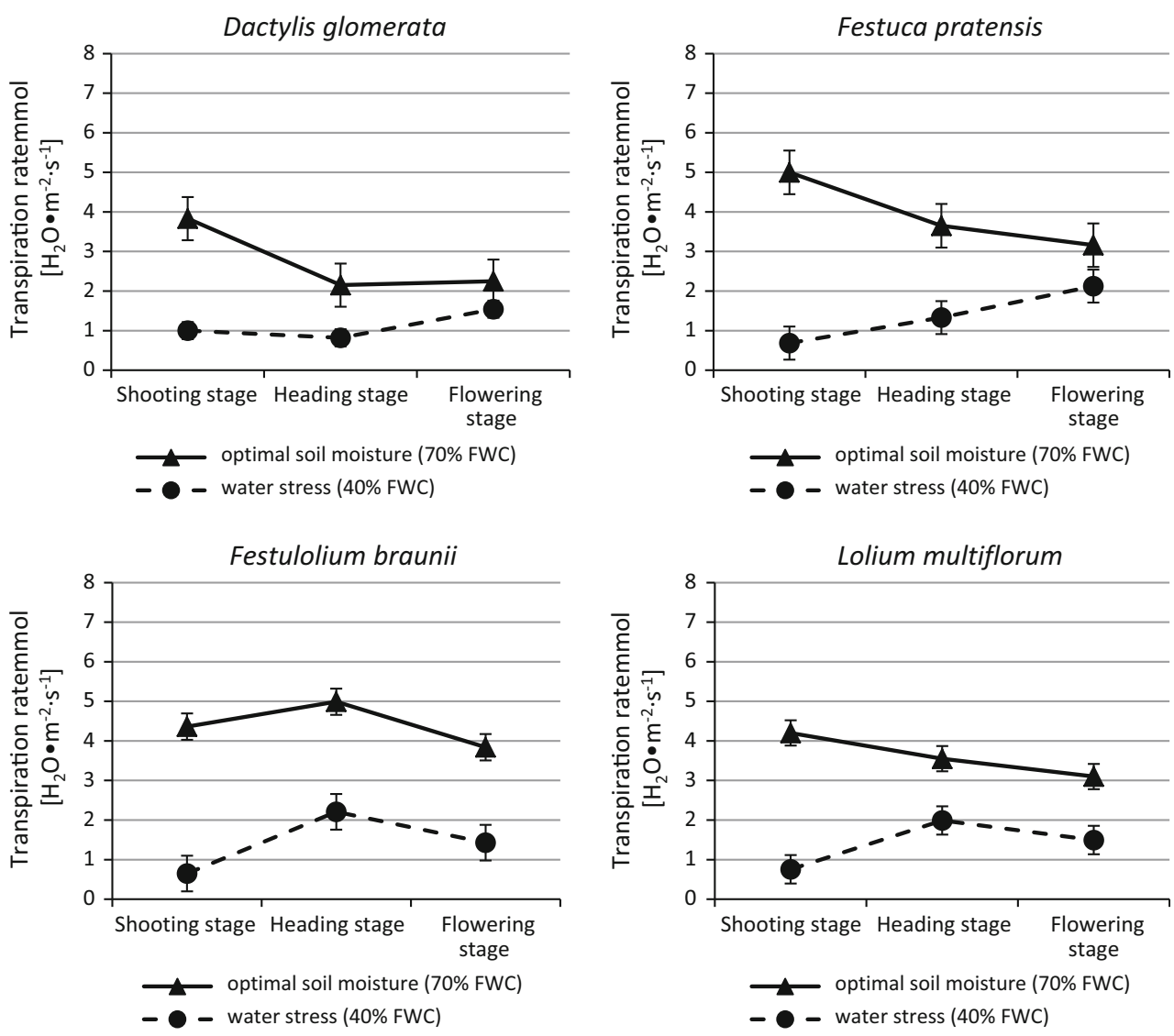

et al. 2004]. The daily demand of grasses for water ranges from 0.5 to $3.0 \mathrm{~kg} / \mathrm{m}^{2}$, and the amount of the transpired water per $1 \mathrm{~m}^{2} /$ year of turf grass is almost $1000 \mathrm{~kg}$ (Thomas 1994). The literature data show that the droughts in Poland, especially in the summer, accompanied by high temperatures, may cause a decrease in the yield of grasses by about $30 \%$ (Łabędzki 2006b). The yield is an excellent measure of the tolerance to such a shortage of water, which reduces the growth, but does not lead to drying of the plant, which is very common in our climatic conditions. In agricultural practice, the reduction in yield caused by a specific stress factor is the best indicator of the tolerance to this stress (Dziadczyk 2002). The studies of Olszewska et al. (2010) showed that long-term water stress conditions (35\% FWC) caused a significantly reduction in the yielding of five pasture grass species. The smallest reduction in dry matter yield was recorded for L. perenne (49\%) and the highest for $F$. pratensis (68\%) (Fig. 4). Own research (Staniak 2013) has also shown that the prolonged drought stress (40\% FWC) significantly reduces the yield of grasses (Fig. 5). Among the four studied species, the smallest decrease in the yield of dry matter was found in $D$. glomerata (28\%), and the largest in F. braunii $(40 \%)$. Also Madziar and Latanowicz (1996) indicated D. glomerata as a species which is significantly more resistant to

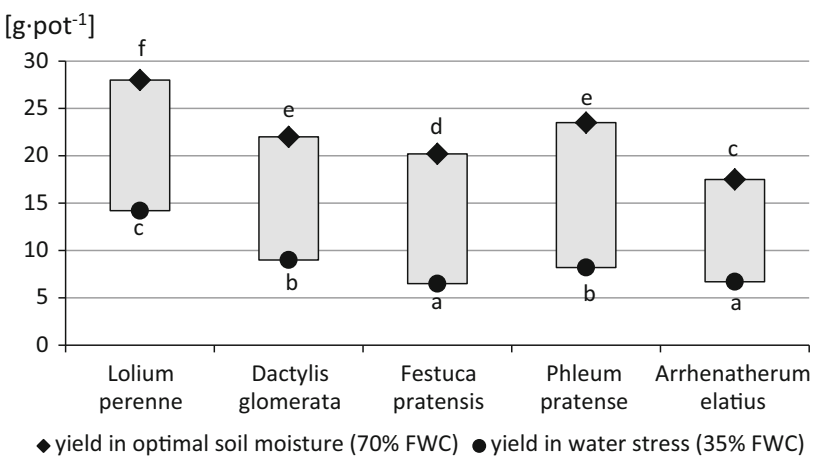

Fig. 4 Decrease of dry matter yield (average of three cuts) of selected forage grasses under conditions of drought stress (own elaboration on the basis of Olszewska et al. 2010)

drought than $F$. pratensis and Ph. pratense. KochanowskaBukowska (2001) reported on significant differences in the yielding of different grass cultivars within a species. According to this author, among the four cultivars of $D$. glomerata, the highest yields, both under the conditions of shortages, as well as the optimum soil water content, were recorded for Astera cultivar, and the lowest for Potomac cultivar (Fig. 6). Taking the decrease of yield as a criterion to measure the resistance may be useful for the final evaluation of the effectiveness of breeding procedures 


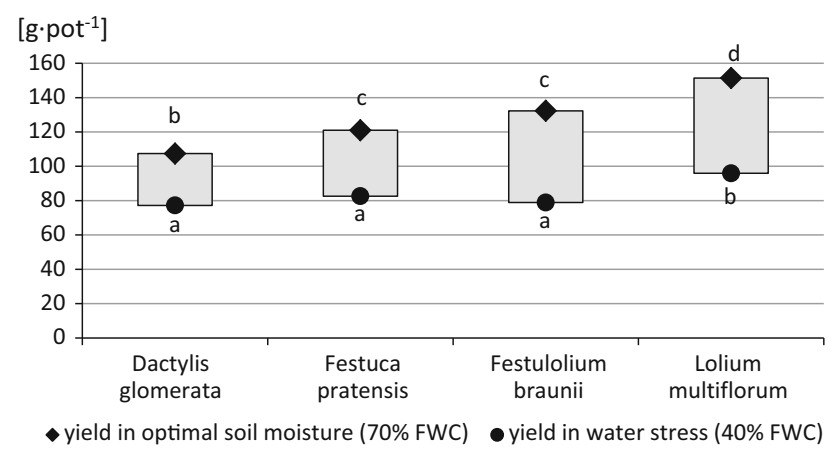

Fig. 5 Decrease of dry matter yield (sum of three cuts) of selected forage grasses under conditions of drought stress (own study)

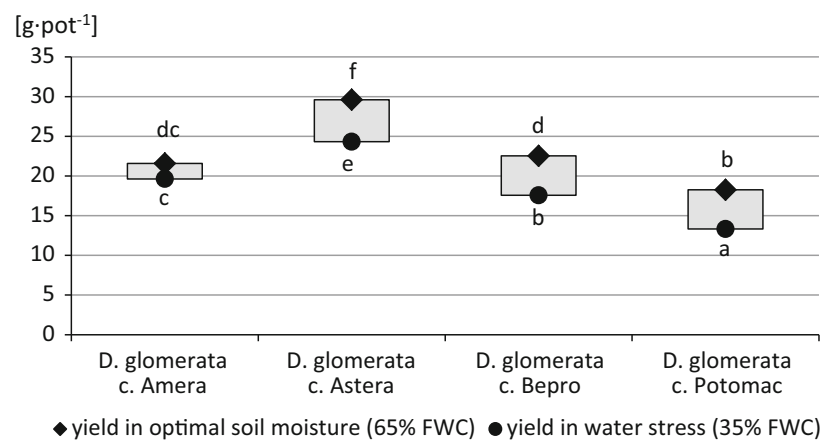

Fig. 6 Decrease of dry matter yield (average of four cuts) of the selected cultivars of $D$. glomerata under conditions of drought stress (own elaboration on the basis of Kochanowska-Bukowska 2001)

based on specific resistance criteria, which have a high selection value. However, it should be noted that the level of agricultural yield results from the interaction of genotype with different environmental factors occurring during the entire growing season. Only conducting the studies under controlled conditions allows to eliminate the effect of other environmental factors and to limit the duration of soil drought to a specific time or development stage (Araus et al. 2002; Kacperska 1991).

\section{Regrowth after dehydration}

The ability to regrow after drought is an important feature of grasses. Together with the water loss, the organism gradually inhibits metabolic processes, and during the reabsorption, the organism is rapidly hydrated and metabolic processes are reactivated. The degree of dehydration tolerance shows the differences in the resistance of different species and grass cultivars to stress, but it can also indicate adaptation possibilities of plants. Drought-tolerant species are able to survive about $30 \%$ dehydration, while maintaining the ability of complete regeneration after hydration, while the plants tolerating dry up survive the loss of even
$92 \%$ of water and show the ability to rehydrate and quickly restore vital signs. These are so-called poikilohydric plants (resurrective), which include some of the types of desert grasses, such as Sporobolus, Eragrostis, and Oropetium (Bernacchia and Furini 2004). Dried grasses can survive up to 2 years, and after rehydration, a regeneration of intensity of basic physiological processes occurs within a few dozens of hours. One of the conditions for the survival of such a strong dehydration of these plants is a protection against destruction of genetic apparatus and cell membranes, mainly by the participation of different stress proteins, or by an increase in the concentration of the cell sap in the cytosol, resulting, among others, from the synthesis of large amounts of carbohydrates (Starck 2005).

Leaf buds, which tolerate much lower values of the osmotic potential than the fully developed leaf blade, and which initiate the subsequent regrowth of plants, are the key organs that determine survival of periods of water shortages in the grasses. The dieback of leaves during the prolonged absence of water facilitates the movement of proteins, fats, and other macromolecules to the organs such as buds of young leaves, flowers or seeds, from which the plant will be able to regenerate after receding of drought (Volaire 2003). The own results showed that pasture grasses such as $D$. glomerata, $F$. pratensis, $F$. braunii, and L. multiflorum, after a prolonged drought stress in the first year of growth, achieved a full recovery in the second year of vegetation characterized by an optimum soil moisture (70 \% FWC), and the obtained yields of dry matter were on average by $7.5 \%$ higher than those with the grasses not subjected to stress (40\% FWC) in the first year (Table 2). L. multiflorum showed the best regeneration abilities (yield increase by $11.5 \%$ ), while $F$. braunii the weakest (yield increase by $3.8 \%$ ) (Staniak 2013).

\section{Breeding grasses for resistance}

We have no influence on the occurrence of drought, but we can to some extent modify the sensitivity of plants to extreme weather conditions, among others, by the appropriate use of soil, rational water management, adaptation of crops to natural habitats, or the appropriate location of farms. The water needs of plants can greatly reduce also a biological progress in agriculture, because an increase in agricultural production must not be accompanied by an increase in water consumption. The introduction of the "thrifty" cultivars with greater efficiency and lower habitat and agronomic demands allows the cultivation of such plants in smaller areas, with no major losses in productivity and lower stress on the environment. Advances are being made in breeding cultivars resistant to biotic and abiotic stresses, including drought. At present, due to using the techniques of genetic engineering, it is possible to introduce genes which 
Table 2 Dry matter yield of grasses depending on the moisture level of the soil (own study)

Table 3 Yielding capacity of different cultivars of $L$. perenne under drought stress (Jurek 1994)

\begin{tabular}{|c|c|c|c|c|c|c|c|c|}
\hline \multirow[t]{3}{*}{ Species } & \multicolumn{4}{|c|}{ DM yield in the first year $\left(\mathrm{g} \mathrm{pot}^{-1}\right)$} & \multicolumn{4}{|c|}{ DM yield in the second year $\left(\mathrm{g} \mathrm{pot}^{-1}\right)$} \\
\hline & \multicolumn{2}{|c|}{$\mathrm{K}^{*} 70 \% \mathrm{FWC}$} & \multicolumn{2}{|c|}{$40 \% \mathrm{FWC}$} & \multicolumn{2}{|c|}{ K $70 \% \mathrm{FWC}$} & \multicolumn{2}{|c|}{$70 \%$ FWC } \\
\hline & $\mathrm{g}$ & $\%$ & $\mathrm{~g}$ & $\% * *$ & $\mathrm{~g}$ & $\%$ & $\mathrm{~g}$ & $\%$ \\
\hline Dactylis glomerata & 107.4 & 100 & 72.5 & 67.5 & 123.7 & 100 & 132.6 & 107.2 \\
\hline Festuca pratensis & 121.0 & 100 & 74.5 & 61.6 & 129.8 & 100 & 139.6 & 107.5 \\
\hline Festulolium braunii & 132.3 & 100 & 76.4 & 57.7 & 133.4 & 100 & 138.4 & 103.8 \\
\hline Lolium multiflorum & 151,4 & 100 & 87.5 & 57.8 & 133.3 & 100 & 148.6 & 111.5 \\
\hline Mean & 128.0 & 100 & 77.7 & 61.2 & 130.0 & 100 & 139.8 & 107.5 \\
\hline
\end{tabular}

* $\mathrm{K}$ control object

** \% relative yield in relations to the control object

\begin{tabular}{llllll}
\hline Cultivar & \multicolumn{2}{l}{ The first year of utilization } & & \multicolumn{2}{l}{ The second year of utilization } \\
\cline { 2 - 3 } \cline { 5 - 6 } \cline { 5 - 6 } & Yielding capacity* $^{2}$ & Coefficient of variation & & Yielding capacity & Coefficient of variation \\
\hline Anna & $69.97^{\mathrm{a}}$ & 16.34 & $40.38^{\mathrm{a}}$ & 16.12 \\
Argona & $63.55^{\mathrm{b}}$ & 15.19 & $39.67^{\mathrm{a}}$ & 12.65 \\
Nadmorski & $60.31^{\mathrm{bc}}$ & 19.70 & $37.38^{\mathrm{ab}}$ & 20.57 \\
Arka & $56.90^{\mathrm{c}}$ & 21.53 & $33.08^{\mathrm{bc}}$ & 18.29 \\
Maja & $49.87^{\mathrm{d}}$ & 33.53 & $25.77^{\mathrm{cd}}$ & 27.08 \\
Solen & $47.46^{\mathrm{d}}$ & 26.22 & $29.13^{\mathrm{d}}$ & 15.96 \\
\hline
\end{tabular}

Values in the same column followed by a different letter are significantly different $(p<0.05$; Tukey's test) * The percent of dry matter yield of plants under drought stress (35\% FWC) as compared to the control $(60 \%$ FWC)

increase tolerance to adverse environmental factors into the genome of plants susceptible to environmental stress. High hopes are laid onto intraspecies and interspecies hybrids, which combine advantageous features of the parental species in their genome. They are a valuable source of variation for increasing resistance to abiotic and biotic stresses. One of such hybrids is Festulolium braunii, the effect of the crossing of L. multiflorum and F. pratensis (Sulinowski 1968). Parent species easily intersect and their chromosomes have sufficient homology, so they can be conjugated and recombined in the hybrids. The works on the complex hybrids of Lolium-Festuca have been conducted for many years in various research centers in Poland (Zwierzykowski et al. 1998, 1999) and in Europe (Fojtik and Vacek 1983; Ghesquière et al. 1996; Jadas-Hecart et al. 1991; Levis et al. 1973; Netzband 1990; Thomas and Humphreys 1991).

Breeding plants resistant to soil drought are very complex because the genes responsible for the reaction of plants to water stress are located in different chromosomes and their activity is sometimes coupled with the influence of other genes. In addition, the final effect is strongly modified by environmental conditions and depends on the plant development stage (Dziadczyk 2002). According to Maximov (cited by Gej 1961), each plant organ is the most sensitive to water shortage in the most intense phenophase. This is a critical period when the plant is extremely sensitive to the stress factor. In the case of forage grasses, this period occurs at the end of vegetative development and the beginning of the creation of generative organs (Staniak 2013). The studies of Jurek (1994) showed that the course of phenomena related to the effects of water deficit on the growth and development of the perennial plants, such as grasses, should be tested taking into account the time factor, as young plants (in the first year of utilization) respond differently to older plants (in the third year of utilization) (Table 3). The own studies using different cultivars of $D$. glomerata, $F$. pratensis, $F$. braunii, and $L$. multiflorum also showed that young plants in the first year of vegetation were less responsive to drought (yields lower by an average of $35 \%$ ) than older plants in the second and third year of use (yields lower by an average of $49 \%$ ) (Staniak 2013).

\section{Summary}

Knowledge of the basic physiological and genetic reactions of grasses to various environmental factors is insufficient. More frequent drought periods in Poland and other countries indicate the need for doing research to find out about the reactions of individual species and cultivars of forage grasses to adverse environmental factors and about their adaptation and acclimatization capacities to the changing conditions. This will allow for the selection of species 
which are more resistant to drought and breeding cultivars with higher adaptation capabilities and higher tolerance to water deficits in the soil.

Author contribution statement The workshop behind this article was conceived by Mariola Staniak. Mariola Staniak and Anna Kocon contributed to the research analysis and discussion that forms the basis of this article. Writing was led by Mariola Staniak.

Open Access This article is distributed under the terms of the Creative Commons Attribution 4.0 International License (http:// creativecommons.org/licenses/by/4.0/), which permits unrestricted use, distribution, and reproduction in any medium, provided you give appropriate credit to the original author(s) and the source, provide a link to the Creative Commons license, and indicate if changes were made.

\section{References}

Araus JL, Slafer GA, Reynolds MP, Royo C (2002) Plant breeding and drought in $\mathrm{C}_{3}$ cereals: what should we breed for? Ann Bot 89:925-940

Bạk B (2004) Climatic conditions of Wielkopolska and Kujawy region. Woda Środ Obsz Wiej 3(9):14-38

Bąk B, Łabędzki L (2003) Modification of standardized precipitation index SPI for drought monitoring in Poland. W: Meteorological services' tasks in NATO operations, missions and exercises. 5th Intern Symp Military Meteorology Poznan, 29.09.20032.10.2003 Warsaw, WAT, pp 15-22

Bandurska H (1999) The role of proline in the response of plants to water deficit in the light of the research results. Zesz Probl Post Nauk Rol 469:31-42

Bandurska H, Górny AG, Zielezińska M (2008) Effects of water deficit on the relative water content, proline accumulation and injury of cell membranes in leaves of old and modern cultivars of winter wheat. Zesz Probl Post Nauk Rol 524:115-126

Bernacchia G, Furini A (2004) Biochemical and molecular responses to water stress in resurrection plants. Physiol Plant 121:175-181

Blum A (2009) Effective use of water (EUW) and not water-use efficiency (WUE) is the target of crop yield improvement under drought stress. Field Crops Res 112:119-123

Bokhari UG, Trent JD (1985) Proline concentrations in water stressed grasses. Range Manag 38:37-38

Carrow RN (1996) Drought avoidance characteristic of diverse tall fescue cultivars. Crop Sci 36:371-377

Chaves MM, Oliveira MM (2004) Mechanisms underlying plant resilience to water deficits: prospects for water-saving agriculture. J Exp Bot 407:2365-2379

Doroszewski A, Jadczyszyn J, Kozyra J, Pudełko R, Stuczyński T, Mizak K, Łopatka A, Koza P, Wróblewska E (2012) Fundamentals of the agricultural drought monitoring system. Woda Srod Obszary Wiej 12 2(38):77-91

Drought in Poland (reasons, intensity, extent, conclusions for the future) (2006) Report IMiGW, Warsaw, p 33

Dziadczyk P (2002) Genetic tolerance to abiotic stress in plants. Zesz Probl Post Nauk Rol 481:49-60

Eagles CF, Thomas H, Volaire F, Horwath CJ (1999) Stress physiology and crop improvement. In: Proc of the XVIII Int Grassland Congress, Winnipeg, Saskatoon, Canada, 3, pp 141-150

EEA-European Environment Agency (2004) Impacts of Europe's changing climate. An indicator based assessment, Luxemburg,
Office for Official Publications of the European Communities, pp 107

Farooq M, Wahid A, Kobayashi N, Fujita D, Basra SMA (2009) Plant drought stress: effects, mechanisms and management. Agron Sustain Dev 29:185-212

Fojtik A, Vacek V (1983) Evaluation of intergeneric hybrids Lolium multiflorum Lam. + Festuca sp. div. and their parental generations 1 Yield characteristics. Sbornik Vedeckych Praci 8:107-117

Gej B (1961) The resistance of plants to water deficit. Wiad Bot 5(2):135-144

Ghesquière M, Emile J, Jadas-Hécart J, Mousset C, Traineau R, Poisson C (1996) First in vivo assessment of feeding value of Festulolium hybrids derived from Festuca arundinacea var. glaucescens and selection for palatability. Plant Breed 115:238-244

Górski T, Kozyra J, Doroszewski A (2008) Field crop losses in Poland due to extreme weather conditions: case studies. In: Liszewski S (ed) The influence of extreme phenomena on the natural environment and human living conditions. ŁTN, Łodź, pp 35-49

Hanson AD, Hitz WD (1982) Metabolic responses of mesophytes to plant water deficits. Ann Rev Plant Physiol 33:163-203

Hanson AD, Nelsen CE (1985) Water: adaptation of crops to drought conditions. In: Carlson PS (ed) Biology yields. PWRiL, Warsaw, pp 79-152

Hull RJ (1997) Managing turf for minimum water use. Turf News 21(2):24-28

Hura T, Hura K, Grzesiak M, Rzepka A (2007) Effect of long-term drought stress on leaf gas exchange and fluorescence parameters in $\mathrm{C}_{3}$ and $\mathrm{C}_{4}$ plants. Acta Physiol Plant 29:103-113

IPCC-Intergovernmental Panel on Climate Change (2014) Climate changes 2014 Synthesis Report. Summary for Policymakers http://www.ipcc.ch/pdf/assessment-report/ar5/syr/SYR_AR5_SPM corr1.pdf. Accessed 19 December 2014

Jadas-Hecart J, Poisson C, Scehovic J, Zwierzykowski Z (1991) Potential of tetraploid hybrids between Lolium multiflorum and Festuca arundinacea var. glaucescens. In: Proc of the XVII Meeting Fodder Crops Sect. of EUCARPIA, Alghero, Italy, 14-18 October 1991, pp 145-147

Jones HG (1998) Stomatal control of photosynthesis and transpiration. J Exp Botany 49:387-398

Jones MB, Leafe EL, Stilles W (1980) Water stress in field-grown perennial ryegrass. I. Its effects on growth, canopy photosynthesis and transpiration. Ann Appl Biol 96:87-101

Jurek M (1994) Variability of response of perennial ryegrass (Lolium perenne L.) to drought. Genet Pol 35A:127-134

Kacperska A (1991) Plant resistance to abiotic stress factors of the environment and methods of evaluation. Post Nauk Rol $1-2: 21-33$

Kacperska A (2004) Sensor types in signal transduction pathways in plant cells responding to abiotic stressors: do they depend on stress intensity. Physiol Plantarum 122:159-168

Kalaji MH, Łoboda T (2010) Chlorophyll fluorescence in the studies of the physiological condition of plants. SGGW, Warsaw, p 116

Karolewski $\mathrm{P}$ (1996) Role of proline in higher plants under conditions of abiotic stress. Wiad Bot 40(3/4):67-81

Kochanowska-Bukowska Z (2001) Reaction of selected orchard grass (Dactylis glomerata L.) cultivars to soil moisture. Electron J Pol Agric Univ, Agronomy 4(2) www.ejpau.media.pl. Accessed 19 December 2014

Kozyra J, Doroszewski A, Nieróbca A (2009) Climate change and their expected impact on agriculture in Poland. Studia Rap IUNG-PIB Puławy 14:243-257

Krupa Z, Baszyński T (1989) Environmental stresses as factors modifying the structure of the light-harvesting chlorophyll $\mathrm{a} / \mathrm{b}$ protein complex II. Phytosynthetica 23:695-698 
Łabędzki L (2006a) Agricultural droughts—an outline of problems and methods of monitoring and classification. Woda Środ Obsz Wiej Rozpr Nauk Monogr IMUZ Falenty 17:1-107

Łabędzki L (2006b) Droughts and floods-a threat to agriculture. In: Water in the agricultural landscape. Woda Środ Obsz Wiej, Rozpr Nauk Monogr, IMUZ, Falenty, 18:29-43

Lawlor D (1995) Photosynthesis, productivity and environment. J Exp Bot 46:1449-1461

Levis EJ, Tyler BF, Chorlton KH (1973) Development of LoliumFestuca hybrids. Rep Welsh Plant Breed Station for 1972:34-37

Madziar Z, Latanowicz M (1996) The productivity and nutrient content in crops of selected forage grass species in pot combination under different soil moisture conditions. PTPN, Wydz. Nauk Rol Leś Prace Kom Nauk Rol Kom Nauk Leśn 81:129-135

Mioduszewski W (2006) Water in rural areas. Woda Środ Obsz Wiej 1(16):277-295

Munns R, Scharp RE (1993) Involvement of abscisic acid in controlling plant growth in soils of low water potential. Aust J Plant Physiol 20:425-437

Nalborczyk E (1996) Selection and use of modern measurement and control equipment in the field experimentation. vol. I Determination of gas exchange, spatial structure and energy balance of photosynthetic active radiation in the field. Zesz Probl Post Nauk Rol 447:81-90

Netzband K (1990) Breeding of tetraploid Festulolium fodder grasses with different maturity. Proc of the 16th Meeting of the Fodder Crops Section of Eucarpia, Wageningen, Netherlands, 18-22 November 1990, pp 47-48

Olszewska M (2006) Effect of water stress on physiological processes, leaf greenness (SPAD index) and dry matter yield of Lolium perenne and Dactylis glomerata. Pol J Nat Sci 21(2):533-562

Olszewska M (2009) Response of cultivars of meadow fescue (Festuca pratensis HUDS.) and timothy (Phleum pratense L.) grown on organic soil to moisture deficiency. Acta Sci Pol. Agricultura 8(1):37-46

Olszewska M, Grzegorczyk S, Olszewski J, Bałuch-Małecka J (2010) A comparison of the response of selected grass species to water stress. Grassland Sci Pol 13:127-136

Ozturk A, Ayolin F (2004) Effect of water stress at various growth stages on some quality characteristics of winter wheat. J Agron Crop Sci 190:93-99

Paul M, Pellny T, Goddijn O (2001) Enhancing photosynthesis with sugar signals. Trends Plant Sci 6:197-200

Paulo AA, Pereira LS (2006) Drought concepts and characterization. Comparing drought indices applied at local and regional scales. Water Intern 31(1):37-49

Revenga C, Brunner J, Henninger N, Payne R, Kassem K (2000) Pilot analysis of global ecosystems: freshwater systems. World Resources Institute, Washington, pp 1-100

Rumasz-Rudnicka E (2010) Influence of irrigation and nitrogen fertilizer on assimilation and transpiration of westerwolds ryegrass. Acta Agroph 15(2):395-408

Staniak M (2013) Response of selected species and cultivars of forage grass to water shortage in the soil. Mongr Rozpr Nauk 38:1-217

Starck Z (1995) Response of plants to unfavorable environmental conditions in aspects of source-sink relationships. Post Nauk Rol 3:19-35
Starck A (2002) Integration of biomass partitioning in the whole organism includes total export from photosynthate donors and partitioning of assimilates between various sinks. Zesz Probl Post Nauk Rol 481:113-123

Starck Z (2005) Plant responses to the abiotic environmental stresses-aclimatization and adaptation. Grassland Sci Pol 8:173-184

Starck Z (2010) Effect of stress conditions on coordination of photosynthetic production and resources allocation. Post Nauk Rol 1:9-26

Statistical yearbook of agriculture in Poland (2013) GUS, ZWS Warsaw http://stat.gov.pl/en/topics/statistical-yearbooks/. Accesed 19 December 2014

Sulinowski S (1968) Interspecific and intergeneric hybrids in grasses of Festuca and Lolium genera. Genet Pol 4(112):25-45

Thomas H (1994) Diversity between and within temperate forage grass species in drought resistance, water use and related physiological responses. Aspects of App. Biol Eff Water Use Crop Syst 38:47-55

Thomas H, Humphreys M (1991) Progress and potential of interspecific hybrids of Lolium and Festuca. J. Agric Sci Cambr 117:1-8

Van Peer L, Nijs I, Reheul D, De Cauwer B (2004) Species richness and susceptibility to heat and drought extremes in synthesized grassland ecosystems: compositional VS physiological effects. Funct Ecol 18:769-778

Vierling E, Kimpel JA (1992) Plant responses to environmental stress. Curr Opin Biotechn 3:164-170

Volaire F (2003) Seedling survival under drought differs between an annual (Hordeum vulgare) and perennial grass (Dactylis glomerata). New Phytol 160:501-510

Volaire F, Leliévre F (2005) How can resistant genotypes of Dactylis glomerata L. survive severe Mediterranean summer drought? pp 145-148 http://ressources.ciheam.org/om/pdf/c62/04600148. pdf. Accesed 19 December 2014

Water in a Changing World. The United Nations World Water Development Report 3-WWDR3 (2009) UNESCO, pp 1-313

Wigley TM, Raper SC (2001) Interpretation of high projections for global-mean warming. Science 293:451-454

Wilman D, Gao Y, Leitch MH (1998) Some differences between eight grasses within the Lolium-Festuca complex when grown in conditions of severe water shortage. Grass Forage Sci 53:57-65

World Meteorological Organization (WMO) (2004) Weather. Clim Water Sustain Dev 974:1-34

Xu ZZ, Zhou GS (2005) Effects of water stress and high nocturnal temperature on photosynthesis and nitrogen level of a perennial grass Leymus chinensis. Plant Soil 269:131-139

Zwierzykowski Z, Tayyar R, Brunell M, Łukaszewski AJ (1998) Genome recombination in intergeneric hybrids between tetraploid Festuca pratensis and Lolium multiflorum. J Hered 89(4):324-328

Zwierzykowski Z, Łukaszewski AJ, Naganowska B, Leśniewska A (1999) The pattern of homologous recombination in triploid hybrids of Lolium multiflorum with Festuca pratensis. Genome 42:720-726 